Indicative World Plan for Agricultural Development", limits discussion to effective economic demand rather than need. He points out that gifts of food to countries with malnourishment often do more ultimate harm than good, and suggests that it would be better so to organize things that the people of these countries could earn more money and buy the food. It would seem to be still better so to organize things that they can grow the necessary food locally.

People with a mystical belief in "natural" foods are roundly trounced, and many examples are given of tho indubitably beneficial cffects of food processing. Examples are also given of potentially harmful processing undertaken for trivial or purely commercial reasons. Pyke recognizes that one cannot generalize about the activities of food manufacturers. They need watching, but tho watchers should not become paranoid. The standards that are sometimes now set would have condemned rhubarb, and even perhaps the potato, had they operated when these plants were introduced into Europe.

An excellent final pair of chapters discuss population problems and the potentialities of synthctic foods, the extraction of leaf protein, and the cultivation of edible microorganisms on agricultural wastes and petroleum. Here, and at many other points in the book, Pyke stresses the need for greatly increased research; wo know, for example, very little about the food needs of the elderly. He shows commendable scepticism of the simple explana. tions sometimes given for recent population increases and argues that they are not caused simply by medical progress but by many forms of technological innovation. A little technological change is welcome, but ho secs the risk that too much may make life unbearable and produce plethora -not just of food, but of noise, crowding and pollution as well.

N. W. PIRIE

\section{TOOLS FOR PLANT BREEDERS}

\section{Induced Mutations in Plants}

(Proceedings of a Symposium on the Nature, Induction and Utilization of Mutations in Plants, joirtly organized by the IAEA and FAO, and held at Pullman, Washington, 14-18 July 1969. Proceedings Series.) Pp. 748. (International Atomic Energy Agency: Vicnua; HMSO London, 1969.) 517 schillings; $166 s 8 d ; \quad \$ 20$.

Mutations occur spontaneously, but rarely. Radiation and mutagenic chemicals are tools with which the plant breeder may induce more variation for selcetion, but mutations are chance events and, unless understood and controlled, induced mutations as a weapon in the breeder's armoury might be compared with trying to hit the bullseye with a shotgun; one may be successful but the target has to be rebuilt. This book constitutes the published papers of a symposium intended to review our understending of the use of induced mutations in plants.

The symposium was divided into seven sections. Section A consists of nine papers on the nature of mutations, genotics and biochemical pathways; section B, fifteen papers on the action of physical and chemical mutagens; section $\mathrm{C}$, four papers on the induction of mutations and breeding methods in vegetatively propagated species; section $D$, fifteen papers on induced mutations and breeding methods in seed-propagated species; section $\mathbf{E}$, seven papers on the utilization of mutations for general and evolutionary studies; section $F$, three papers on the use of chromosome aberrations in breeding; and section $G$, three papers on new induced mutant varieties. Of the fifty-eight papers, fifty-two are in English and all are preceded by brief summarics in English. Excepting D and E, the first paper in each section is chiefly devoted to a comprehensive review (with extensive bibliography) of the topic under discussion.

The papers in section A provide evidence for incrcasing sophistication of techniques. R. D. Brock's paper on "Increasing the Specificity of Mutation", for example, describes experiments with Escherichia coli which indicato that certain mutagens will mutate an active gene more readily than when it is inactive. Also, by using the regulator protein of the lactose operon, made mutagenic by incorporating ${ }^{35} \mathrm{~S}$ and ${ }^{3} \mathrm{H}$ amino-acids, ho opens up the prospect of inducing mutations at particular loci. If similar systems are operative in higher plants, refined control of the mutagenic processes may be possible.

References to the successful use of induced mutations are many. Theso include the use of ncutrons and $\mathrm{X}$-rays to inducc Verticillium resistant strains of peppermint, by M. J. Murray (section C); the use of X-ray induced translocations to produce the first commercial $F_{1}$ hybrid barley, by R. T. Ramage (scetion D); the ability to increase the yield of barley some 10 per cent above that of the mother variety, described by members of the Max Planck Institute (section D); not to mention the scores of released crop varieties described and listed in section $\mathrm{G}$.

In section $\mathrm{E}$, along with papers on the "Tetrasomic Heredity of Induced Mutations in Arabidopsis thaliana" and the "Nature of Chromosome Deletions", R. F. Stettler and co-workers discuss the interesting possibility of producing homozygous forest trees by induced haploid parthonogenesis. The diversity of the papers in section $B$ supports the view of M. S. Swaminathan that brecders should continue to use a wide range of mutagens.

Theso proceedings may be of particular interest to British plant breedors who, in a list of one hundred and one participants from twenty-five countries, are sadly noticeable by thoir absence.

G. R. MaCTAY

\section{ESSENTIAL NUTRIENTS}

Trace Elements in Agriculture

By Vincent Sauchelli. Pp. viii +248 . (Van Nostrand Reinhold: New York and London, January 1970.) $140 s$. VINCENT SAUChELLI died in autumn 1969 after a long life in agricultural science, latterly in association with the American fertilizer industry. This is his last book; it was written as a survey for the general reader and student and as background information for advisers, teachers and fertilizer manufacturers who meet trace element problems in their daily work. It succeeds in these aims.

The first five chapters are introductory. They describe the historical background to trace element research, and biological and physico-chemical relationships of crops and soils involving trace elements. This information is simply but accurately presented and will be useful to both students and to those who need to refresh their memories.

Six chapters follow on the trace elements or micronutrients which are well recognized as being ossential to plants -iron, manganese, boron, rine, molybdenum and copper. These chapters have a general pattern. Sources of trace elements in soils, the effects on plants of deficiencies and surpluses, and the effects of each element on animal health and nutrition are described. The mothods used to correct deficioncies are discussed well; the tables setting out recommendations for different crops and soils in parts of the United States are parlicularly valuable features of some of the chapters. There is a chapter on chlorine, the latest element to be accepted as essential for plants, but which is much moro important in animal nutrition and health.

Sodium seems to be essential for a few plants and can substitute for potassium in others. There is a chapter on sodium, but it gives very little information about the importance of this element in animal nutrition. But sodium is hardly a trace elemont, eithor for plants or animals, and the account is out of place in this book. 